\title{
Rural Development Theorising: Reinventing a Model of Financing Basic Rural Infrastructure in Nigeria
}

\author{
Uno Ijim Agbor \\ Department of Public Administration, University of Calabar, Calabar, Nigeria \\ E-mail: kenijim@yahoo.com
}

Received: June 5, 2019 Accepted: July 1, 2019 Published: July 2, 2019

doi: 10.5296/jsss.v6i2.15014 URL: https://doi.org/10.5296/jsss.v6i2.15014

\begin{abstract}
The burden of rural development has remained recurrent in the development planning of Nigeria from independence to date. Despite these concerns, the condition of the rural areas in terms of development infrastructure remains precarious. The development of rural infrastructure is highly central to the transformation of rural areas of Nigeria yet attention in that direction seems unproductive. Several methods of effecting rural development have been applied in the Nigerian context with little or no major inroad into addressing rural infrastructure and reversing the rural squalor common in the country. This paper argues that the pool method (central determination) of financing basic rural infrastructure is prone to excluding so many communities from accessing basic facilities and falls short of the practice of accountability. On the basis of this, the paper recommends a model of financing basic rural infrastructure known as FINANCIAL EQUITY MODEL. It is the thesis of this paper that further financial administration restructuring at the Local Government system will provide a plausible vent for a quick and even development of rural areas in Nigeria.
\end{abstract}

Keywords: Rural development, Financial, Infrastructure, Equity

\section{Introduction and Background: The Rural Situation and Development Approaches in Nigeria}

The development question remains an unanswered question in the development praxis of Nigeria. The consistent interrogation of this question underscores the importance of development to human existence. One of the defining features of the Nigerian rural localities in recent years has been the constant promise by government and donor agencies to transform the rural communities to more life enhancing and attractively habitable localities. Whether these promises manifest into concrete realities or not remains the confusion surrounding the debate on patterns of rural infrastructure financing in Nigeria as well as the gap between what 
is desired and what is provided. The provision of hard infrastructure such as roads, electricity and which provides the basis for the emergence of soft infrastructure such as banking, credit, extension services, transport, communication and marketing of rural produce seems highly elusive in the development equation of rural locales in Nigeria. The pronouncement of government has always been to accelerate change at the rural level with a view to improving the rural infrastructure and encourage a good standard of living. In actual sense, given the poor state of rural localities of Nigeria, the government's desire and effort to transform the local areas by promising the needed infrastructure should be concrete and consistent.

Rural Nigeria harbors over 80 percent of its citizens under life threatening conditions. From the perspective of participant observer, rural infrastructure is weak leading to poor accessibility of local areas. The setback has always been that farm produce from local areas hardly find their way to the urban market for better value. The pricing of local commodities has always remained low because movement in and out of the producing locality has always been hampered by poor road infrastructure. This obviously affects the rural economy and makes the rural people constantly poor when compared to those persons who attempt a living in the urban areas.

The World Bank Transport Business Strategy (2008-2012) observes that about 1.2 billion people of the world mostly of the poor do not have access to an all-weather road. It argues further that between 40-60 percent of people living in the Third world countries stay very far from healthcare facility. It takes about $8 \mathrm{~km}$ to get to a health centre. Again in some regions less than 15 percent of roads are paved. Effective rural transport system is a sine qua non to rural development and poverty reduction

Utilities such as pipe borne water and electricity are thoroughly in short supply in most Nigerian rural areas. Without the availability of rural infrastructure such as good roads, pipe borne water, electricity, health facilities and educational infrastructure the emergence of soft infrastructure such as banking, communication facilities, credit, extension services which provide the basis for wealth creation in rural areas may likely be ephemeral. Where these facilities are not found in rural localities the issue of making progress in rural transformation is but mere lip service.

The utility of effective exercise in basic rural infrastructure development is diverse. It could among others lead to the followings:

- Opens the rural areas to viable economic activity.

- Reduces the mass movement of people to the urban areas in search of better living.

- Creates more viable revenue point for government.

- There is the tendency to improve the living standard of the people and greater self-actualization.

- Curtails the wanton villagisation of urban areas arising from the practice of rural values brought by rural-urban migrants.

Effective exercise in rural infrastructural provision will among others address these issues raised above. The depressed condition common in rural localities of Nigeria requires a committed effort at rural infrastructure provision to alleviate it. Basic amenities such as 
health and medical facilities, rural transportation facilities, electricity, pipe-borne water and schools lie at the core of enhancing the capacity of the rural localities.

The rural areas in Nigeria have been described as backward, uninhabitable, life threatening and numbed. Its inhabitants are regarded as the neglected majority, stagnant unit of the Nigerian economy and associated with poverty (Olatunbosun, 1973 and Ijere, 1992). About 50-80 percent of the adults are illiterate and there is general lack of infrastructure and poverty cycle that is viscious (Anaeto, 2003). The rural area is embroiled in misery, poverty, morbidity and under development (Obeta \& Okide, 2018). World Bank statistics show that the percentage of poverty among the rural population stood at 51.4 percent in 1985 and rose to 69.8 percent in 1996 (World Bank, 2005). The figure has risen again to about 80 percent in 2017 (Business Insider, 2018).

Greater number of the rural dwellers experience insecurity and vulnerability especially in the areas of drought, flooding, disease, volatile commodity markets (World Bank, 2005). Life in rural areas of Nigeria is hard, rustic and sometimes inhuman (Anele, 2012).

Attempts to overcome these precarious conditions have brought about the establishment of programmes aimed at developing the rural areas both in infrastructure and in human capacity.

Over the years, series of interventions directed at improving the nature of rural localities have been carried out. Nigerian government has in all its development plans emphasizes rural transformation as a measure to decongest the urban areas and encourage sufficient self-reliance among rural people. This it encouraged and still encouraging through diverse rural development programmes such as ADP (1972), River Basins (1979), DFRRI (1986), NDDC (2000). International agencies such as USAID, UNO, World Bank, European Union have also shown tremendous interest in transforming rural communities of Africa by instituting some intervention programmes to improve rural infrastructure. With the various strategies implemented so far in Nigeria, the rural area still wears nasty and ugly look (Karmar, Lawal, Babangida, \& Jahun, 2014). All these efforts seem not to reflect positively on the infrastructure statuses of rural localities. While some of these strategies have been acknowledged to attempt a minimal change at the rural areas, some have failed woefully (Raheem \& Bako, 2014).

On monthly basis, both the state and local governments collect quite substantial amount of money as allocation from the federation account over the years and little or nothing seem to show in basic infrastructure provision in the rural areas. The question is; what could account for this failure? Could the nature and pattern of distributing local government finances accounts for the dearth of basic infrastructure in rural localities of Nigeria? Could effective exercise in financial administration restructuring at the local government level provide the needed panacea to rural development infrastructure in Nigeria? Here lies the problematique of this paper.

\section{Objective, Justification and Method}

The objective of this paper therefore, is to configure a financial distribution model that can effectively bring about even basic rural infrastructure development and distribution.

This study is necessary in view of the deteriorating condition of rural areas and the effect such deterioration poses on the stability of the Nigerian state. Without effective exercise in 
rural infrastructure, achieving the Sustainable Development Goal (SDG) in Nigeria will certainly be a mirage. Again failure in accountability of public finance especially at the local level further justifies the need for this paper. The Danger of the Top-Bottom approach (the danger of acting against the need of local areas) commonly practiced in Nigeria's distribution of infrastructure makes this exposition relevant. It is a scholarly exercise in rural development theorizing that suggest an approach in Development Administration and Local Government financial distribution.

The paper adopted the documentary method as its method of data collection. The documentary methods are "techniques used to categorize, investigate, interpret and identify the limitations of physical sources and most commonly written documents whether in the private or public domain (Payne \& Payne, 2004). The method involves the analysis and interpretation of documents by the researcher to give voice and meaning around the issue under study (Bowen, 2009).

The paper studied and analyzed written and graphic materials that carried vital information that were relevant to the study. Documentary method of data collection is a scientific and acceptable method of data collection in social science research which applies rigorous adherence to research ethics (Mogalakwe, 2009). This is one of the oldest methods of data collection in Political Science and Public Administration (Obasi, 1999). Data analysis was qualitatively done with the use of a schema.

\section{Financing Rural Infrastructure}

Diverse forms of financing rural infrastructure exist globally. While in some climes, the government directly provides infrastructure by centrally contracting the jobs to construction firms to carryout, others adopt partnership strategy and in some they give loan facilities to rural people to provide the type of infrastructure that addresses their peculiar needs. Some forms of financing rural infrastructure include the followings:

\subsection{Central Planning (the Pool System)}

Central government intervention in rural infrastructure provision has remained a consistent approach to financing rural amenities. O'Neill (2014) work on financing of rural infrastructure and services, trends achievements and challenges align with this trend. His position points to an institutional option of setting up contracts execution agency were one central government ministry can coordinate local government roads. The operational mechanics of this option involves the central management of projects. In the case of some communities in the United States, South Central Planning and Development Commission has been instrumental in the implementation of "major infrastructure projects in the village of Napoleonville (Assumption Parish) and rural towns of Convent, Gramercy, Lockport and Lutcher in St. James Parish" (www.scpdc.org). Central planning and execution of infrastructure seems a common practice among countries such as Abania, Azerbarjan, Croatia and Romania. In the Central Planning method, the government solely makes the decision concerning what infrastructure to provide and how it is executed. It determines which area of the locality gets what, how and when as against a decision emanating from the interaction between citizens and the government on their felt-needs. The people (in this case the 
community) do not have a choice over what they need and how it is supplied. Development is delivered directly from the centre without involving the rural recipients

The advantage of this method is that it stems down duplication since allocation of resources is centrally done. The disadvantages are diverse:

- It breeds inefficiency

- It wears a command structure and therefore dictatorial

- It determines which locality gets what and when. It therefore, can exclude some communities from being considered in the distribution of resources of the state.

- In the case of backward societies such as Nigeria, it is extremely opened to diverting public funds to private concerns.

- It does not give room for mobilization of resources

- There is the likelihood of ignoring societal needs

- Coordination is often difficult in a command economy (Lombardo, 2018).

\subsection{Public Private Partnership}

Public Private Partnership remains another approach to financing infrastructure at the rural areas. It has become an increasingly popular method in the field of international development. Donor institutions have come to consider this approach as a more sustainable way of building infrastructure in rural communities and developing countries.

Its utility is captured in Ferguson (1990) and amplified by Belt and Spierenburg (2013) as the most logical solution to a variety of service delivery and development problems and is often presented as technical, politically neutral solutions. Again, government can carry out essential projects that require huge financial outlay such as rural infrastructure development which government does not have the required money. This strategy reduces the risk of budgetary incapability to fund needed development programmes.

Often, funds are limited to address public demands especially in developing countries. Nigeria in particular has witnessed abandoned project syndrome owing largely to lack of money to continue. The practice has left the country with myriads of abandoned projects littered around the country. The solution to this lies as argued by proponents of Public Private Partnership in the transfer of some of those risks to the private sector. It is a development strategy that is fast occupying the Nigerian development landscape and is considered a seeming panacea to Nigeria's challenge in building needed infrastructure not only at the rural level but also at urban centres.

According to Raphael (2012) Public Private Partnership "is a contractual arrangement between a public and private entity which includes a certain degree of transfer of risk to the private entity with the benefit of remuneration and has an emphasis on meeting a social need or fulfilling a development project which is intended for the public good". This strategy seems too fresh in the rural development strategy of Nigeria. The PPP model seems to be working well in countries such as Canada, UK, Australia, Continental Europe and Latin America. The governments in these countries have nurtured the PPP model by responding to changing market conditions basically through reforms and innovations. However, there are countries whose PPP is still fragile. The United States and Asia even though are among the 
largest economies of the world have very week PPP framework. Asia, for instance is gradually keying into the model but start up has been very slow. United States PPP development is stunted by slow development of institutional frameworks and standard processes. PPP in Africa has been extremely very sluggish. Some of the constraints faced by PPP in Africa are; limited financial markets, inadequate legal and regulatory frameworks, absence of technical skills within government agencies and political and national risks among others (www.ey.com)

\subsection{Loan Schemes}

In some climes, financing rural infrastructure assumes the dimension of offering loan facilities to rural individuals to address their peculiar infrastructural needs. In the case of USA such measures are very common and especially extended to local farmers. This option is mostly operational and effective in the provision of simple infrastructure that does not require huge financial outlay such as mobile phones for farmer communication with extension officers, purchase of trucks for the evacuation of farm produce etc.

\section{Approaches to Rural Infrastructure Development in Nigeria}

Infrastructure is the foundation upon which other development structures of society rest. It is an umbrella that encapsulates and propels activities that bring about improvement in human life. Olase and Alade (2012) relying on the assumptions of development economics refers to infrastructure as "social overhead capital"; an aspect of structure of society that galvanizes many other activities for social and economic stability. The social infrastructure in this context will include among others such outfits as basic health facilities, education and water facilities. Other infrastructures which fall under economic and often considered a precondition for industrialization include roads, markets, and telecommunication, electricity, and agro-allied industries.

Yusuf (2007) also identifies farm input supplies, dams and canal works for irrigation, postal services, sewage, solid waste collection and disposal as part of economic infrastructure. The availability of these infrastructures propels the possibility of growth in all aspects of economic endeavours of the rural place. Put succinctly, there can be no substantial inroad to socio-economic development of the rural areas without a corresponding qualitative and quantitative infrastructure (a base upon which improved economic activities hinges). So many approaches have been adopted by Nigeria to address rural infrastructure. Some are discussed below.

\subsection{Directorate for Food, Road and Rural Infrastructure (DFRRI)}

Understanding the importance of improved infrastructure especially at the rural localities has prompted government to adopt various policy measures to bring about the needed infrastructure at the rural areas. One policy measure was the adoption of the Directorate for Food, Road and Rural Infrastructure (DFRRI) in 1986. The basic responsibility of the Directorate was to guarantee adequate rural infrastructure that can improve rural life and narrow the gap in infrastructure between the urban and rural localities. The operational mechanics of DFRRI was the opening up of rural roads to provide access to farm produce of rural dwellers as well as basic infrastructure such as bore holes rural housing, electricity and storage facilities. 
The popular arguments remain that this approach was fundamentally defective and contributes nothing to addressing the infrastructural predicaments of rural localities in Nigeria. Adenipekun (2013) shares this view when he submitted that the implementation of the DFRRI policy "launched a discriminatory provision of the basic infrastructural facilities in selected areas of the country". Rather than reduce the imbalance in social and economic infrastructures between the rural and urban localities, DFRRI exacerbated the gulf and kept rural communities in a more uncertain condition.

Ering, Otu and Archibong (2014), Ocheni and Nwankwo (2012) and Ikeji (2013) in their separate studies analysed the failure of DFRRI to address the infrastructural needs of rural localities. Among other factors that led to the collapse of DFRRI was the lack of culture of continuity of government policies. Ocheni and Nwakwo (2012) for instance argue that DFRRI suffered a sustainability problem arising from the absence of effective community participation strategy. This was a major bane of DFRRI. Ikeji argues the failure from the stand point of corruption, bad policies associated with location of projects, award of contracts and resource allocation.

\subsection{Agricultural Development Project}

Improving the state of agricultural activities in the rural areas was also considered a viable approach to improving rural infrastructure in Nigeria. One government policy in that direction was the Agricultural Development Project (ADP) which idea was muted in 1972 by the Nigeria government in conjunction with the World Bank. The pilot study began in 1976 in Funtua, Gombe and Gussau and the successes recorded in these areas led to the establishment of the 31 ADPs in Nigeria (Ocheni \& Nwankwo, 2012). The programme was aimed at raising rural income through improved agricultural practice associated with standard infrastructure.

The basic assumption of the programme was that there will be improvement in the standard of living of the rural people when agricultural cultivation is improved and resuscitated. This improvement will come when there is availability and combination of the following factors:
$>$ Improved technology
$>$ Extension services
$>$ Basic Infrastructural facilities
$>$ Improved market
$>$ Appropriate physical inputs

The programme had in its delivery system the following:

- Water projects

- Rural roads development

- Farm input distribution

- Development of small Dams

- Extension Services

The World Bank since 1974 has contributed about $\$ 1.2$ billion to the improvement agricultural productivity through the ADPS in Nigeria. However, the ADP recorded limited success in improving productivity and infrastructure in the rural areas of Nigeria. In actual 
procedure, infrastructure comes before production. Therefore since ADP could not provide the needed infrastructure at the rural areas the goal of improving agricultural productivity also procedurally failed. Independent evaluation of six ADPs which operated between 1979 and 1990 revealed that about two were minimally satisfactory. The rest were colossal failure (World Bank, 2012). The failure of the programme at the level of infrastructural provision may not be unconnected with the gradual withdrawal of the World Bank from the programme. Iwuchukwu and Igbokwe (2012) attributed the failure of the ADP to Shortage of fund due to decline in oil prices that started in 1982 and led to delays in recruiting competent staff and provision or purchasing of materials and facilities needed for the projects take off. Again ADP emphasizes more on modern/ high input technology like sole cropping while majority of the farmers practiced mixed/relay cropping. Other challenges includes high frequency of labour mobility, limited involvement of input agencies, dwindling funding policies and counterpart funding and intricacies of technology transfer (p. 13).

Generally, some of these agricultural development programmes failed for obvious reasons. Some of the reasons were;

- Weak agricultural development policies that were ambiguous and could not spell out specificity for the masses

- Lack of reliable strategies and effective target

- Alienation of some major stakeholders (the rural dwellers). No clear cut interaction among stake holders at the level of planning and implementation. Agriculturalists, researchers, farmers and rural dwellers are often ignored at the critical stages of the development programmes.

- $\quad$ Lack of continuity of programmes

- Inadequate monitoring and evaluation (Okafor, 2017).

\subsection{River Basin and Rural Development Authorities}

The initiative of the Food and Agricultural Organization (FAO) of the United Nations to establish a pilot irrigation situated on the Sokoto - River Basin in 1953 became the forerunner of the river Basin and Rural Development policy of Nigeria. The success of this initiative led to the establishment of the various River Basin Development authorities across Nigeria. It became one of the rural development strategies adopted to fast track the emergence of needed infrastructure at the rural level to improve their income and standard of living.

Decree 25 of 1975 which set up eleven River Basin Authorities guaranteed among others, the following responsibilities of the policy:

$>$ Provide assistance to states and local governments in provision of the following:

* Construction of feeder roads

* Water supply scheme

* Construction of single dams

* Construction of boreholes and wells

* Provide power for rural electrification

$>$ Carry out mechanize clearing and cultivation of land for crop and livestock production. 
Process crops, livestock products and fish produced in the area by farmers.

These functions clearly show the relevance of the policy to rural infrastructure development in Nigeria.

The RBRDA has also been considered a failure in rural infrastructure development. Ikeji (2013) argues that its outing was poor and perhaps paved way for the emergence of DFRRI as an alternative measure. The approaches examined above expresses a centrally coordinated funding of rural infrastructure leaving the higher level governments (State and Federal) with the sole choice of determining, when to intervene, how to intervene where to intervene and what to intervene with.

The problem with these methods of financing rural infrastructure is that in more depraved countries such as Nigeria, most rural communities will be neglected in the development equation of the centrally-determined projects of the top level governments. Again development infrastructure may not be evenly distributed among rural communities that make up the local government areas, largely because the choices of rural communities are centrally determined. They are exclusionist in character, content and delivery.

Again, none of these studies and approaches looked at how rural infrastructure could probably be evolved, sustained and distributed evenly using local government financial allocation specifically. This gap in literature is the central concern of this paper and therefore has come to cover. To this end, the paper contributes to knowledge at this level of scholarship.

\section{Nature of Rural Infrastructure in Nigeria}

Rural infrastructure in Nigeria is poor and nasty. Scholars in Nigeria rural development studies attest to the clear fact that the status of rural infrastructure in Nigeria is so weak that it cannot support the realization of enhanced economic life, and improved standard of living of the rural people. By basic infrastructure the paper looks at those amenities that are fundamentally needed as a necessity to enhance the living condition of the people and restore the dignity of man. They include among others the following:

- Water facility

- Health facility

- Educational facility

- Sanitation facility

- Transport facility

- Feeder road

- Electricity

- Telecommunication

Ale, Abisuwa and Ologunagba (2011) concluded that "The necessary infrastructural facilities that should be a catalyst of encouragement for the farmers are of little or no provision". This setback leaves the rural Nigerian farmer at a consistent level of subsistent farming.

\subsection{Road Network}

Rural roads in Nigeria wear a neglected look and impassable during the wet season. The efforts of some of the rural development programmes initiated manifest in grading earth 
roads that vehicles can use during the dry season. One not encouraging practice that is common is that such roads are graded once in a long while (about 10 to 15 years) if at all government attention is directed at such communities.

Earth roads have their disadvantages. During the dry season, it produces so much dust that local communities and road users are open to heart disorder arising from excessive inhalation of dust. During the wet season, motor vehicles hardly make use of the roads and clearly cuts off rural communities from smooth interaction with the urban areas. The shortcoming is that rural markets become inaccessible thereby bringing down the value of their farm produce and by extension increasing rural poverty and further lower the standard of living. Asphalted rural roads remain the viable option to improving rural access.

Adegboye (2017) portrays the state of roads in Nigeria as deplorable and describes it as a national shame and embarrassment. He based his description on the fact that most of the roads across the nation, "whether Trunk A roads which are federal, or Trunk B which are state roads or Trunk $\mathrm{C}$ roads which are local government roads, are in decadent state, and there is hardly any part of the country that can boast of decent motorable roads. This terrible state of the country's roads has resulted to untimely deaths of innocent Nigerians and foreigners through avoidable accidents. The same poor state of roads has resulted in poor productivity of workers as immeasurable man-hours are lost in traffic on daily basis".

In a paper titled Transportation Infrastructure as a Catalyst for Economic Diversification and Inclusive National Development, Izuwah (2017) argues that "about 135,000 kilometres of road network in the country were un-tarred". Nigeria has about 195,000 km road network out of which a proportion of about $32,000 \mathrm{~km}$ are federal roads while $31,000 \mathrm{~km}$ are state roads. Out of this, only about $60,000 \mathrm{~km}$ is paved. Of the paved roads, a large proportion is in very poor unacceptable condition due to insufficient investment and lack of adequate maintenance".

Sambe (2018) shares similar facts and views. He points out that Nigeria's road network which connects the entire country stretches to $193,200 \mathrm{~km}$. About $28,980 \mathrm{~km}$ (15percent) is paved which lags behind the situation in Malaysia (80 percent) and slightly above Ethiopia (13 percent). Ethiopia, Nigeria, and Malaysia are ranked as the $27^{\text {th }}, 32^{\text {nd }}$ and $66^{\text {th }}$ largest countries in the world by landmass.

There are many consequences of a poor road network as put forward by Sambe. The danger it poses to human lives is ranked the most grievous. Accident statistics on Nigerian roads as presented by Sambe showed that in July 2017 alone, 13 people died from car accidents each day resulting to about 403 deaths in that month alone. Over 1,200 vehicles were involved in accidents during the same month

Enwerem and Ali (2016) had studied the Economic effects of bad roads on vehicle maintenance in Nigeria. They discovered that "All unpaved roads which is about 13percent are bad roads. Both the paved and the unpaved roads in Nigeria are deteriorating by the day and has become a source of worry to all vehicle users. Annual losses (from vehicle maintenance), due to bad roads is valued at over N133.8billion. This is outside all other economic losses from bad roads in the areas of air Pollution, delayed movements, armed 
robbery and incessant accidents on the roads. About 51percent of vehicle users in Nigeria will experience one or more damages to the vehicles in a month" (p. 761).

Bad roads in Nigeria cost drivers fortune to maintain their vehicles. This is transferred to cost of transportation borne by passengers through paying higher transport fares. Transporting goods become very expensive and are transferred to the unit cost of commodities thereby exacerbating the already inflationary condition in Nigeria. A World Bank working paper opines that when road networks connecting major locations are put in proper condition, regional trade in Sub-Saharan Africa can spring up by $\$ 250$ billion in five years.

\subsection{Electricity}

Electricity remains one of the engines of development both in the rural and urban centres. While the urban centres enjoy considerable attention in electricity infrastructure development and supply, the rural areas are greeted with sad neglect.

In rural locations where attempts have been made to provide electricity, two things are common (i) the materials provided are abysmally substandard that they collapse and stop functioning the very day they are commissioned.

(ii) Where such installations tarry, those communities hardly have power supply. This is however, not unconnected with the poor wattage generation and distribution in Nigeria. Laure (2003) and REAP (2006) submit that access to electricity in Nigeria is low. They argue that only 40 percent of the entire Nigeria population can access electricity and is worst in the rural communities as only 10 percent has access to it. This state of power supply keeps rural dwellers consistently choiceless as they are continually limited to their age long traditional ways of doing things. The effect remains a reduction in productivity and accentuation of poverty.

\subsection{Educational Facilities}

Rural school facilities are in total shamble. Most children stay in substandard school buildings to receive lectures. School desks are also in short supply as most pupils and students hang or sit on the floor to receive lectures. Very worrisome is the quality of teaching staff at rural schools. Many are poorly trained and therefore have nothing to offer to the students and pupils.

Monitoring by higher authorities is often thwarted by inability to access such schools because of difficult terrain. More experience teachers detest going to rural schools and will always reject such postings because of absence of infrastructure that support scholarship and keeps them comfortable. The output has been the number of functional illiterates produced from various rural schools across the country.

\subsection{Health Infrastructure}

Health is considered wealth. The argument underlying this assertion is that a healthy person is likely to work well and could create higher output than a sick person. In Nigeria rural communities, modern health facilities are in short supply. Some communities do not have a primary health centre. Some will have to trek about 10 kilometers to access a health centre.

This limitation offers the rural people the choices of self-medication and patronage of traditional herbalists - a practice that has damaged the lives of reasonable number of rural 
dwellers. The productive population of the rural areas often loses their lives because of lack of modern medical facilities.

Rural healthcare facilities in Nigeria can hardly provide efficient service delivery. In this regard, Eboreime, Abimbola and Bozzani (2015) conclude that "Nigeria's health care system has been found to operate below standards in terms of the availability of human resources and necessary infrastructure, equipment and medications".

Welcome (2011) asserts that "the Nigerian health care has suffered several down-falls. Despite Nigerian's strategic position in Africa, the country is greatly underserved in the health care sphere. Health facilities (health centers, personnel, and medical equipments) are inadequate in this country, especially in rural areas. While various reforms have been put forward by the Nigerian government to address the wide ranging issues in the health care system, they are yet to be implemented at the state and local government area levels". The 2009 communique of the Nigerian national health conference submits that "health care system remains weak as evidenced by lack of coordination, fragmentation of services, dearth of resources, including drug and supplies, inadequate and decaying infrastructure, inequity in resource distribution, and access to care and very deplorable quality of care".

Abayomi (2017) shares the view that "effective delivery of healthcare services requires availability of adequate infrastructure, diagnostic medical equipment, drugs and well-trained medical personnel" Medical facilities according to Omotoso (2009) "are essential for the overall socioeconomic and political development of any nation. Countries with adequate provision and well-maintained medical facilities are well-off"

\subsection{Water Supply Infrastructure}

Water infrastructure is also in short supply in rural communities of Nigeria. Interventions such as Rural Water Supply and Sanitation Agency, EUMPP6, etc, have not adequately addressed the water need of rural people of Nigeria. The inhabitants still rely on unsafe sources of water for survival. One common experience in the Nigerian case is that large chunk of its population residing in the rural areas draw their water from sources that are dangerous to health. Sources such as open stream, lakes, springs, river, acidic rain remain common among rural dwellers. The practice of open defecation is still common in Nigeria rural communities. When the rain falls it washes their faeces into the stream from where local dwellers draw for consumption. This highly tells on the health status of rural Nigerian as the rate of bacterial infections is common among them. Water sources in rural areas remain highly polluted because of this unsafe practice.

Kolawole, Olayemi Ajayi and Okoh (2011) had discovered while accessing water quality in Asa River, Nigeria that there is high level of faecal pollution of the river. Physicochemical parameters and bacteriological analysis conducted exceeded the recommended level for surface water quality.

In a similar study on water quality assessment in Zaria, Nigeria by Chigor, V. N., V. J. Umoh, C. A. Okuofu, J. B. Ameh, E. O. Igbinosa and A. I. Okoh (2011), the authors discovered that the water bodies in the study area are potentially hazardous to public health. They observe that municipal waste water, storm water runoffs and abattoir effluents among water constituted the sources of contaminating streams and rivers often consumed by people. Water 
pollution is a major predicament of the rural localities of Nigeria and largely accounts for the quantum of health deterioration in rural Nigeria.

\section{Theoretical Foundation}

This paper is anchored on the thesis of two known theories. They are the Felt Needs Theory and the theory of New Public Management. As a community developments theory, the Felt Need theory assumes that community development should strike on the actual need of the people that is considered necessary in order to address the deficiency perceived in these communities.

The theory further assumes that the community expresses its ideas and hopes of what they want as it touches on the reality facing them. Therefore, the opinion and perception of its people are sacrosanct when relying on the Felt Need Model. In diagnosing the problem of the community as well as fixing the problem, the opinion and perception of the communities play significant role.

The theory allows the practice of participatory method largely permitting communities to influence the direction of intervention. The basic idea surrounding the theory is that community development should be more concerned with alleviating the challenges communities are facing.

The basic limitation of the theory is that it is prone to being culture-bound. Since cultural norms are often not questioned or challenged, the status quo in terms of social order may likely remain the same and at the end changes nothing. This limitation is possible when the theory is applied in planning urban development as some influential members of the urban settlement will likely protect the existing pecking order.

The theory of New Public Management emphasizes the application of private sector orientation to administering public affairs. It posits that government should be run like a business. The major proponents include David Osborne and Ted Geabler in their book Reinventing Government. The use of private sector approach in government is the main thesis of the theory. It argues that emphasis should be shifted from the Traditional Weberian Public administration to Public management. The concern of the theory is that the public service should be more businesslike in order to increase its efficiency. The best way to make government more rewarding and achieving is to apply the private sector models in planning and driving public concerns.

The relevance of the NPM to this paper lies on its feature of encouraging efficiency and minimizing wastage. The theory also emphasizes accountability in the public service by applying a model that commits public functionaries to meet the citizens at the point of their needs. The theory emphasizes on a new way of running the public service to guarantee equity and effectiveness. This paper is therefore located within the philosophy of this theory as it seeks to evolve a new model of financing basic infrastructure that guarantees efficiency, accountability and greater achievement with minimal government control.

\section{Financing Basic Rural Infrastructure: The Financial Equity Model}

The general inadequacy of infrastructure in the rural areas of Nigeria is obvious. The various interventions are mere flash on the infrastructural needs of the rural population. Even in the areas affected by government interventions, greater proportion of the people still hold the 
opinion that more needs to be done to actually address the age-long sad neglect by the government. This study submits that there is an approach the Nigerian government can adopt to gradually address the problem of non-existence of basic infrastructure in rural areas of the country.

The study therefore recommends what could be referred to as Financial Equity Model of financing Basic Rural Infrastructure in Nigeria (FEMFBRI). The model is explained in the proceeding mechanics below.

\section{The Operational Procedure of the Model}

Every constitutionally recognized local government in Nigeria draws statutory financial allocation from the Federation account running into millions of Naira from where salaries and development programmes of the local government are addressed. The direction of this model is that the balance of Local Governments allocation from the federation account after salaries and sundry expenditure have been settled is shared among wards. Wards are electoral units that form the legislative councils of a local government. The Wards accumulate this balance over a period of time. The accumulated balance is used directly to provide infrastructure on the Felt Need of the communities (see Figure 1).

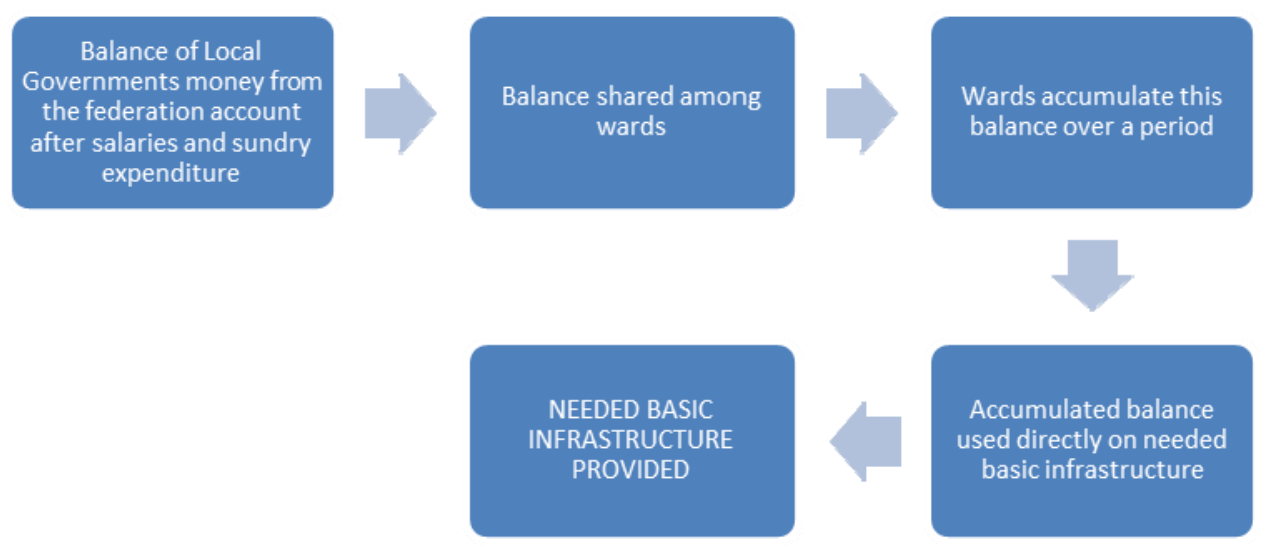

Figure 1. Financial Equity Model of financing basic rural infrastructure (FEMFBRI) Source: Author's conceptualization, 2017.

Parties to the application of the fund include the Councillor representing the ward, the communities, the banks and the Ministry of rural development. The Councillor discusses the needs of the ward at the legislative council and monitors the account balance of the ward at the designated banks. He holds a town hall meeting with his ward every month to intimate them of the revenue accrued to them. He also monitors the progress of projects executed in his ward and reports same to the council.

The communities get involved in the choice and nature of the projects to be executed on the basis of their felt needs. They also monitor the specification of the projects executed to be sure that it was what was designed. The communities through their town unions get involve in cost survey to ensure that the value of the project is not criminally inflated; a common phenomenon in the pool approach which is directed by the centre alone. This is important because bloated project cost impinges negatively on the account balance of the ward. The 
implication of bloated project cost is that there will be limited amount of money to carry out more development projects.

The banks get involve to custody the funds allocated to each wards. It also disburses approved money and monitors contractors to ensure that projects are executed to specification before disbursement of funds is made.

The ministry of rural development and the local government council ensure the equitable allocation of these council surpluses into the accounts of the wards.

\section{The Utility of the Model}

This approach is quite assuring because it has the tendency of reducing corruption. By allocating revenue to the wards, majority of the rural dwellers are brought close to the knowledge of the money meant to provide infrastructure in the localities. They are likely to consistently ask questions that will cause government functionaries to act responsibly given the overbearing presence of the Economic and Financial Crime Commission (EFCC).

The beauty of the approach also lies in its participatory and inclusive structure. In other words it promotes participatory governance. It affords communities the opportunity to be part of the choice of the project to be executed in their wards. It clearly establishes balance in the provision of basic rural infrastructure and allows for community monitoring of projects which effectively guarantees completion to specification. By this vent, substandard projects which remain major characteristic of projects executed under the pool approach (central control) are likely to be drastically reduced.

It will likely ensure spread of basic infrastructure to all parts of the local government almost simultaneously (Even distribution of infrastructure). It will likely evoke in the people a sense of belonging which could generate the necessary support the government needs to function peacefully. The model supports accountability as both the government and the communities will strive to show value for funds transparently allocated to wards.

\section{Statistical Analysis of the Model}

Attempt is made here to run a simple practical explanatory analysis of how the local government surpluses are distributed and what the financial standing of wards will look like using specific cases as point of departure. The paper relies on the allocation to Cross River State local governments for selected months of 2017. First I present the allocation tables for February, May and June. 
Table 1. Federation Account Allocation Committee (FAAC) February 2017 Allocation to Cross River State Local Government Areas

\begin{tabular}{|c|c|c|c|c|c|c|c|c|}
\hline $\begin{array}{c}\text { Local } \\
\text { Government } \\
\text { Councils }\end{array}$ & $\begin{array}{c}\text { Gross Statutory } \\
\text { Allocation }\end{array}$ & $\begin{array}{l}\text { Exchange } \\
\text { Gain } \\
\text { Difference }\end{array}$ & Deduction & $\begin{array}{c}\text { Distribution } \\
\text { of } \mathbf{N 3 6 , 8 0 7 \mathrm { B }} \\
\text { Excess PPT } \\
\text { Savings } \\
\text { Account }\end{array}$ & $\begin{array}{c}\text { Distribution } \\
\text { of N15,885B } \\
\text { Excess PPT } \\
\text { Savings } \\
\text { Account }\end{array}$ & $\begin{array}{c}\text { Distribution } \\
\text { of N8,15B } \\
\text { Excess PPT } \\
\text { Savings } \\
\text { Account }\end{array}$ & $\begin{array}{c}\text { Value Added } \\
\text { Tax }\end{array}$ & $\begin{array}{c}\text { Total } \\
\text { Allocation }\end{array}$ \\
\hline $\mathrm{ABI}$ & $63,093,131.30$ & 5 & 7.5 & $91,036.90$ & $3,448,728.19$ & $1,771,088,93$ & 25,121, & 110,10 \\
\hline AKAMKPA & $79,307,300.63$ & $13,449,467.07$ & $(2,544,453.3$ & $10,044,636.44$ & $4,335,009.49$ & $2,226,237.30$ & $25,456,409.40$ & $132,274,606.96$ \\
\hline AKPABUYO & $75,920,440.29$ & $12,875,100.44$ & $(2,434,582.2$ & $9,615,674.91$ & $4,149,880.61$ & $2,131,164,65$ & $31,824,172.87$ & $134,081,851.52$ \\
\hline BAKASSI & $48,985,197.50$ & $8,307,240.26$ & $(1,558,97.3$ & $6,204,201.83$ & $2,677,575.64$ & $1,375,065.75$ & $19,169,652.65$ & $85,160,235.26$ \\
\hline BEKWARA & $58,516,325.40$ & $9,923,593.23$ & $(1.868,649$ & $7,411,363.26$ & $3,198,555.80$ & $1,642,613.29$ & $23,057,816.33$ & $101,881,617.64$ \\
\hline BIASE & $67,318,691.99$ & $11,416,357.94$ & $(2,154,700$ & $8,526,223.71$ & $3,679,701.19$ & $1,889,704.75$ & $26,412,500.47$ & $117,088,479.98$ \\
\hline BOKI & 77,177, & $3,088,252.38$ & $2,475,446$ & $9,774,865,89$ & $4,218,583.39$ & $2,166,446.85$ & $0,351.41$ & 131 \\
\hline $\begin{array}{l}\text { CALABAR } \\
\text { MUNICIPA }\end{array}$ & 6.54 & 0.69 & 847. & 8.53 & 67.45 & .41 & 1.78 & 109 , \\
\hline $\begin{array}{c}\text { CALABAR } \\
\text { SOUTH }\end{array}$ & $65,163,788.41$ & $11,050,914.85$ & $(2,084,922$ & $8,253,295.20$ & $3,561,912.20$ & $1,829,214.40$ & $27,600,969.64$ & $115,375,172.41$ \\
\hline ETUNG & 51,025 & $553,297.00$ & 05. & 6,462, & 2,789 & $1,432,346.16$ & $21,701,033.20$ & $90,439,224.37$ \\
\hline IKOM & $69,623,965.30$ & $11,807,301.74$ & $(2,231,802$ & $8,818,197.23$ & $3,805,709.54$ & $1,954,416.14$ & $26,052,470.61$ & $119,830,257.96$ \\
\hline OBANLIKU & $60,084,076.97$ & $10,189,463.11$ & $(2,540,598$ & $7,609,926.25$ & $3,284,250.53$ & $1,686,621.69$ & $23,296.177 .28$ & $103,609,917,58$ \\
\hline OBUBRA & $66,221,731.44$ & $11,230,327.97$ & $(2,119,233$ & $8,387,288.58$ & $3,619,740.33$ & $1,858,911,94$ & $26,585,155.97$ & $115,783,923.22$ \\
\hline OBUDU & $62,694,524.87$ & $10,632,160.48$ & $(2,004,350$ & $7,940,551.55$ & $3,426,940.00$ & $1,759,899.64$ & $25,931,913.55$ & $110,381,639.95$ \\
\hline ODUKPANI & $71,114,098.32$ & $10,060,008.55$ & $(2,278,449$ & $9,006,929.47$ & $3,887,161.57$ & $1,996,245.70$ & $27,644,067.33$ & $123,430,061.31$ \\
\hline OGOJA & $66,835,052.85$ & $11,334,339.15$ & $(2,139,279.5$ & $8,464,968,57$ & $3,653,265.04$ & $1,876,128.51$ & $26,556,406.52$ & $116,580,881.07$ \\
\hline YAKURR & $67,098,531.78$ & $11,379,021.68$ & $2,147,660$ & $8,498,339.40$ & $3,667,667.04$ & $1,883,524.63$ & $27,856,167.28$ & $118,235,590.96$ \\
\hline YALA & $73,995,491.44$ & $12,548.654 .63$ & $(2,372,129$ & $9,371,871.24$ & $4,044.661 .15$ & $2,077,129.36$ & $28,618,212.84$ & $128,283,891.45$ \\
\hline $\begin{array}{c}\text { Cross River } \\
\text { Total }\end{array}$ & $1,185,311,791.50$ & 201,0 & $(38,551,266$. & $150,125,221$ & $64,790,225.21$ & $33,272,918.11$ & $467,148,133.71$ & $2,063,11,193.18$ \\
\hline
\end{tabular}

Source: National bureau of Statistics, 2017.

Table 1 shows that the local governments in Cross River State for the month of February got a total of N2,063,110,193.18 (Two billion and sixty three million one hundred and ten thousand one hundred and ninety three naira eighteen kobo). Staff emolument is about N800,000,000 (Eight hundred million naira). 
Table 2. Federation Account Allocation Committee (FAAC) April 2017 Allocation to Cross River State Local Government Areas

\begin{tabular}{|c|c|c|c|c|c|c|}
\hline $\begin{array}{c}\text { Local } \\
\text { Government } \\
\text { Councils }\end{array}$ & $\begin{array}{c}\text { Gross Statutory } \\
\text { Allocation }\end{array}$ & $\begin{array}{c}\text { Exchange Gain } \\
\text { Difference }\end{array}$ & Deduction & $\begin{array}{c}\text { Distribution of 22,259B } \\
\text { Excess PPT Savings } \\
\text { Account }\end{array}$ & $\begin{array}{l}\text { Value Added } \\
\text { Tax }\end{array}$ & Total Allocation \\
\hline $\mathrm{ABI}$ & $64,663,700.08$ & $14,783,462.22$ & $(2,017,457.56)$ & $4,832,651.03$ & $26,534,330.18$ & $108,756,685.94$ \\
\hline AKAMKPA & $81,281,486.53$ & $18,582,632.66$ & $(2,544,453.37)$ & $6,074,583.72$ & $26,892,462.43$ & $130,286,711,97$ \\
\hline AKPABUYO & $77,810,317.53$ & $17,789,051.48$ & $(2,434,582.26)$ & $5,825,165.40$ & $33,704,508,27$ & $132,684,460,42$ \\
\hline BAKASSI & $50,204,579.39$ & $11,477,807.51$ & $(1,558,697.37)$ & $3,752,046.54$ & $20,167,075.19$ & $84,042,811.26$ \\
\hline BEKWARA & $59,972,964.37$ & $13,711,062.80$ & $(1,868,649,67)$ & $4,482,088.21$ & $24326,518.19$ & $100,623,983.92$ \\
\hline BIASE & $68,994,447.09$ & $15,773,560.75$ & $(2,154,70007)$ & $5,156,310.04$ & $27,915,260.50$ & $115,684,878.30$ \\
\hline BOKI & $79,098,495.48$ & $18,083,556.66$ & $(2,475,446.61)$ & $5,911,437.56$ & $28,875,755.00$ & $129,493,797,08$ \\
\hline $\begin{array}{l}\text { CALABAR } \\
\text { MUNICIPAL }\end{array}$ & $62,658,184.84$ & $14,324,959.86$ & $(1,953,847.98)$ & $4,682,768.56$ & $28,493,434.27$ & $108,205,559.55$ \\
\hline $\begin{array}{c}\text { CALABAR } \\
\text { SOUTH }\end{array}$ & $66,785,901.78$ & $15,268,641.52$ & $(2,034,922.28)$ & $4,991,254.08$ & $29,185,649.81$ & $114,147,524.91$ \\
\hline ETUNG & $52,296,953.83$ & $11,955,941.35$ & $(1,625,005.68)$ & $3,908,346.46$ & $22,875,071.56$ & $89,410,317.52$ \\
\hline IKOM & $71,357,105.25$ & $16,313,713.38$ & $(2,231,802.60)$ & $5,332,883.64$ & $27,530,111.15$ & $118,302,010.82$ \\
\hline OBANLIKU & $61,579,741,77$ & $14,078,405.42$ & $(2,540,593.25)$ & $4,602,170.96$ & $24,581,509.72$ & $102,301,229.62$ \\
\hline OBUBRA & $67,870,180.05$ & $15,516,530.00$ & $(2,119,233.01)$ & $5,072,287.78$ & $28,099,952.26$ & $114,439,727.08$ \\
\hline OBUDU & $64,255,171.19$ & $14,690,064.05$ & $(2,004,350.13)$ & $4,802,119.56$ & $27,401,142.76$ & $109,144,147.43$ \\
\hline ODUKPANI & $72,884,331.95$ & $16,662,869.07$ & $(2,278,449.64)$ & $5,447,021.15$ & $29,232,754.45$ & $121,948,526.58$ \\
\hline OGOJA & $68,498,768.78$ & $15,660,238.42$ & $(2,139,279.57)$ & $5,119,265.45$ & $28,069,206.96$ & $115,206,200.03$ \\
\hline YAKURR & $68,768,806,45$ & $15,721.974 .63$ & $(2,147,660.84)$ & $5,139,446.75$ & $29,459,652.73$ & $116,942,219.72$ \\
\hline YALA & $75,837,451.20$ & $17,338,013,34$ & $(2,372,129.21)$ & $5,667,722.94$ & $30,274,866.63$ & $126,745,924.90$ \\
\hline Cross River Total & $1,214,817,597.56$ & $277,732,481.11$ & $(38,551,266.10)$ & $90,789,569.83$ & $493,620,332.05$ & $2,038,408,717.45$ \\
\hline
\end{tabular}

Source: National bureau of Statistics, 2017.

Table 2 captures a total allocation of $\mathrm{N} 2,038,408,717.45$ (Two billion and thirty eight million four hundred and eight thousand seven hundred and seventeen naira forty five kobo). Emoluments of council personnel is about N780,000,000.00. 
Table 3. Federation Account Allocation Committee (FAAC) June 2017 Allocation to Cross River State Local Government Areas

\begin{tabular}{|c|c|c|c|c|c|}
\hline $\begin{array}{c}\text { Local Government } \\
\text { Councils }\end{array}$ & $\begin{array}{c}\text { Gross Statutory } \\
\text { Allocation }\end{array}$ & $\begin{array}{c}\text { Exchange Gain } \\
\text { Difference }\end{array}$ & Deduction & $\begin{array}{l}\text { Value Added } \\
\qquad \text { Tax }\end{array}$ & Total Allocation \\
\hline $\mathrm{ABI}$ & $69,957,404.23$ & $14,561,950.16$ & $(2,017,457.56)$ & $26,013,095.18$ & $108,514,992.02$ \\
\hline AKAMKPA & $87,936,608,43$ & $18,304,194,70$ & $(2,544,453.37)$ & $26,377,300.58$ & $130,072,650.34$ \\
\hline AKPABUYO & $84,180,271.63$ & $17,522,504.36$ & $(2,434,582.26)$ & $33,304,863.98$ & $132,573.057 .70$ \\
\hline BAKASSI & $54,314,585,31$ & $11,305,826.64$ & $(1,558,697.37)$ & $19,537,865.33$ & $83,599,579.92$ \\
\hline BEKWARA & $64,882,660.70$ & $13,505,619.34$ & $(1,868,649.67)$ & $23,767,843.49$ & $100,287,473.86$ \\
\hline BIASE & $74,642,688.53$ & $15,537,213.29$ & $(2,154,700.07)$ & $27,417,443.09$ & $115,442,644.85$ \\
\hline BOKI & $85,573,906,46$ & $17,812,595.75$ & $(2,475,446.61)$ & $28,394,225.50$ & $129,305,281.10$ \\
\hline CALABAR MUNICIPAL & $67,787,707.17$ & $14,110,317.91$ & $(1,953,847.98)$ & $28,005,482.46$ & $107,949,659.56$ \\
\hline CALABAR SOUTH & $72,253,340.31$ & $15,039,859.65$ & $(2,084,922.28)$ & $28,710,392.42$ & $113,918,670.10$ \\
\hline ETUNG & $56,577,181.28$ & $11,776796.23$ & $(1,625,005.68)$ & $22,291,783.46$ & $89,020,755.29$ \\
\hline IKOM & $77,198,766.09$ & $16,069,272.39$ & $(2,231,802.60)$ & $27,025,762.45$ & $118,061,998.33$ \\
\hline OBANLIKU & $66,620,977.18$ & $13,867,457.78$ & $(2,540,598.25)$ & $24,027,159.12$ & $101,974,995.83$ \\
\hline OBUBRA & $73,426,383.19$ & $15,284,033.83$ & $(2,119,233.01)$ & $27,605,277.00$ & $114,196,461.01$ \\
\hline OBUDU & $69,515,531.06$ & $14,469.951 .45$ & $(2,004,350.13)$ & $26,894,607.03$ & $108,875.639 .41$ \\
\hline ODUKPANI & $78,851,019.45$ & $16,413,196.41$ & $(2,278,449.64)$ & $28,757,278.90$ & $121,743045.11$ \\
\hline OGOJA & $74,106,431.44$ & $15,425,588.95$ & $(2,139,279.57)$ & $27,574,000.15$ & $114,966,740.98$ \\
\hline YAKURR & $74,398,575.79$ & $15,486,400.12$ & $(2,147,660.84)$ & $28,988,024.88$ & $116,725,339.95$ \\
\hline YALA & $82,045,896.27$ & $17,078,224.47$ & $(2,372,129.21)$ & $29,817,063.04$ & $126,569,054.57$ \\
\hline Cross River Total & $1,314,268,834.52$ & $273,571,003.42$ & $(38,551,266.10)$ & $484,509,463.08$ & $2,033,798,039.91$ \\
\hline
\end{tabular}

Source: National bureau of Statistics, 2017.

Table 3 presents a total allocation of N2,033,798,039.91 (Two billion and thirty three million seven hundred and ninety eight thousand ninety one kobo). The personnel monthly remuneration is about $\mathrm{N} 785,000,000.00$.

In simple term, the position here is that the balance of local government allocation from the federation account after salaries and money for sundry expenditures have been deducted should be shared on Ward basis. A collection of this money over a period of time can be substantial enough to put in place basic infrastructure in those wards. When it is done this way over a period of five years, many rural communities of the country would have been visited with at least two basic infrastructures.

A simple analysis with Biase Local Government Area will present the following scenario. The allocation collected by Biase Local Government Council for the month of February was N117,088,479.98 (One hundred and seventeen million, eighty eight thousand four hundred and seventy nine naira ninety eight kobo) (NBS, 2017). After Salaries, allowances and other sundry expenditures the council was left with about N62,088,479.98 (sixty two million eighty eight thousand four hundred and seventy nine naira ninety eight kobo). When you split this amount among eleven wards, each will have about N5,644,407.27 (five million six hundred and forty four thousand four hundred and seven naira twenty seven kobo). It should however 
be noted that allocation to local governments varies every month. On this strength the paper took an average of N5,000,000.00 a month for each council ward. This therefore would leave every council ward with annual allocation of about N60,000,000.00 (Sixty million naira). Basic infrastructure such as providing standard boreholes, primary education facilities as well as health and basic sanitation infrastructure can be consistently provided. If this is consistently done within a period of few years most rural communities will wear a habitable look and provide the local people the opportunity of developing their potentials without necessarily thinking of outward migration. This would reduce fleecing of public treasury at that level of government. It is argued vehemently here that this will ensure spread of basic infrastructure to all parts of the state almost simultaneously. At the same time, it will evoke in the people a sense of belonging which could generate the necessary support the government needs to function peacefully. Infrastructures that require huge financial outlay such as electricity can be identified by the state government and funded. Pool expenditure as is the case now is prone to more corruption and that is why nothing significant is coming from local government councils compared to the amount of money allocated to them.

In drawing this analysis, the paper took into consideration the fact that Local Government Councils are empowered by the constitution to generate revenue internally. Such revenue if effectively driven can assist in addressing to greater extent the sundry and day to day internal administrative cost of the local government. In this case greater portion of the amount from the federation account allocation committee will go into funding basic rural infrastructure. Local governments therefore, must scale up their internal revenue generation effort.

The State House of Assembly should pass laws directing this new formula of revenue allocation at the local government level suggested by this study. The states should also hands off local government money and sincerely supervise the commitment of this money as recommended to basic infrastructure provision. The transformative strength of this approach would show greater achievement by the government in a short while.

We need to clearly understand that what Donor Agencies provide in most cases are mere handout and can hardly solve the infrastructure problem of the rural communities. These programmes will not intervene in the area of electricity. They will carefully avoid it because of the huge financial outlay involved. This is to show that there is a limit to which foreign assistance can go. Internal effort needs to be coordinated for effective rural infrastructural development in Nigeria.

The point the paper is making is that needless of relying and calling on International agencies and foreign donor regimes to come and develop the rural areas of Nigeria, neither should we continue to rely on the pool method of financing basic rural infrastructure because they can hardly go very far in equitably providing basic infrastructure in rural communities. We need a model that equitably provide the basic amenities needed to turn the rural communities into a resemblance of semi urban features to make people stay there and address their life requirements without thinking of moving to the urban areas. The internal approach (FEMFBRI) suggested by this paper can perform this feat faster if properly harnessed. 


\section{Conclusion}

Infrastructure is the core of development anywhere in the world. Its absence or short supply is an invitation to limited productivity and retrogression. The recognition of this fact has made responsible countries of the World to take infrastructural development seriously. Nigeria's infrastructural outlay is weak and even more precarious in the rural areas. Attempt by the state to address this shortcoming has manifested in the implementation of various rural infrastructural programmes. The results have been unsatisfactory with so many rural communities groping in atavistic traditional conditions that fertilize poverty.

Investment in rural infrastructure is likely to produce multiple impacts on the economic behavior of the rural people and reduces the level of poverty in those areas. Fan, Hazell and Thorat (2000), Fan and Hazell (2001) have submitted in separate studies that the provision of rural infrastructure by public commitment has had tremendous improvement in agricultural productions and a reduction in rural poverty. FHT (2000) discovered after studying state level data of India from 1970- 1993 that expenditure on road infrastructure had tremendous impact on productivity growth. Financing rural infrastructure from their arguments involves planning at state level to get a needed infrastructure provided.

The paper has argued that pool method adopted by government to provide basic rural infrastructure is not only exclusionist in delivery but prone to corruption; a serious factor that has contributed to poor government outing at the rural areas in terms of basic infrastructure. This paper argues that inadequate quantity and quality of rural infrastructure has a serious debilitating effect on the nature and the performance of the rural areas.

In order to overcome this backwardness, this paper suggests a model of financing basic rural infrastructure known as The FINANCIAL EQUITY MODEL. The model by its operational procedure guarantees even distribution of the commonwealth of the local government in terms of basic infrastructure to its communities. The model supports accountability and promotes participatory governance.

\section{References}

Abayomi, S. O. (2017). Assessment of primary health care facilities' service readiness in Nigeria. BMC Health Services Research, 17(172). https://doi.org/10.1186/s12913-0172112-8

Adenipekun, M. T. (2013). Sustainable rural infrastructural development in Nigeria within the context of Vision 20:2020. International Journal of Development and Sustainability, 2(1), 254-269.

Adegboye, K. (2017, July 25). No Motorable Roads in Nigeria. Vanguard. www.vanguardngr.com

Ale, M. O., Abisuwa, T. A., Ologunagba, F. O., \& Ijarotimi, O. (2011). Rural Infrastructural Development, Food Security and City Congestion In Nigeria. JORIND, 9(1), 1596-8308.

Anaeto, F. C. (2003). Concept of Rural Development In Nigeria: Issues, Prospects, Problemsand Solutions. Nigerian Academic Forum, 4(2).

Anele, D. (2012). A brief note on the condition of rural areas in Nigeria. A brief note on the condition of rural areas in Nigeria. 
Belt. J., \& Spierenburg, M. (2013). Public Private Partnership in Rural Development; Down playing the role of Politics and Power Relations-DPRN Two. Rozenburg Quarterly.

Bowen, G. A. (2009). Document Analysis as a qualitative research method. Qualitative Research Journal, 9(2), 27-40. https://doi.org/10.3316/QRJ0902027

Business Insider. (2018). World Bank says Nigeria's poverty level increased slightly in 2017.

Chigor, V. N., Umoh, V. J., Okuofu, C. A., Ameh, J. B., Igbinosa, E. O., \& Okoh, A. I. (2012).

Water Quarterly Assessment: Surface water sources used for drinking and irrigation in Zaria, Nigeria are a public health hazard. Environmental Monitoring and Assessment, 184, 3389-3400. https://doi.org/10.1007/s10661-011-2396-9

Eboreime, E., Abimbola, S., \& Bozzani, F. (2015). Access to Routine Immunization: A Comparative Analysis of Supply-Side Disparities between Northern and Southern Nigeria. PLoS ONE, 10(12), e0144876. https://doi.org/10.1371/journal.pone.0144876

Enwerem, G. C., \& Ali, G. A. (2016). Economic Effects of Bad Roads on Vehicle Maintenance in Nigeria. International Journal of Scientific and Research Publications, 6(6), 761-766.

Ering, S. O., Out, J. E., \& Archibong, E. P. (2014). Rural Development Policies in Nigeria: A Critical Appraisal. International Journal of Education and Research, 2(9), 307-320.

Ey. (2018). Public Private Partnerships and the Global Infrastructure Challenge.

Fan, S., Hazell, P., \& Thorat, S. K. (2000). Impact of Public Expenditure on Poverty in Rural India. Economic and Political Weekly, 35, 3581-3588.

Fan, S., \& Hazell, P. (2001). Returns to Public Investment in Less Favoured Areas of India and China. American Journal of Agricultural Economics, 83(5), 1217-1222. https://doi.org/ 10.1111/0002-9092.00270

Ferguson, J. (1990). The Anti-Politics Machine. Cambridge: Cambridge University Press

Ikeji, C. C. (2013). Rural Infrastructural Development in Nigeria: Policies And Implementation Strategies. Developing Country Studies, 3(6), 122-128.

Ijere, M. O. (1992). Leading Issues in Nigeria Rural Development. Enugu: ACENA Publishers.

Iwuchukwu, J. C., \& Igbokwe, E. M. (2012). Lessons from Agricultural Policies and Programmes in Nigeria. Journal of Law, Policy and Globalization, 5, 11-21.

Izuwah, C. (2017). Transportation Infrastructure as a Catalyst for Economic Diversification and Inclusive National Development.

Kamar, Y. M., Lawal, N. I., Babangida, S. I., \& Jahun, U. A. (2014). Rural development in Nigeria: problems and prospects for sustainable development. The International Journal of Engineering And Science, 3(12), 24-29.

Kolawole, O. M., Ajayi, K. T., Olayemi, A. B., \& Okoh, A. I. (2011). Assessment of Water Quality in Asa River, Nigeria and its indigenous clarias gariepinus fish. International Journal of Environmental Research and Public Healt, 8(11), 4332-4352. https://doi.org/10.3390/ ijerph8114332

Laurie, P. (2003). Nigeria Energy Report; Norton Rose.

Lombardo, C. (2018). 16 Main Advantages and Disadvantages of command Economy. 
Mogalakwe, M. (2009). The Documentary Research Method-Using Documentary Sources in Social Research. Eastern Africa Social Science Research Review, 25(1), 43-58. https://doi.org/10.1353/eas.0.0006

National Bureau of Statistics. (2017). Federation Account Allocation Committee; February, April and June. Abuja: Office of the Accountant General of the Federation.

Nigeria National Health Conference. (2009). Communique. Abuja, Nigeria.

Obetta, K. C., \& Okide, C. C. (2018). Rural Development Trends in Nigeria: Problems And Prospects.

Ocheni, S., \& Nwankwo, B. C. (2012). Analysis and Critical Review of Rural Development Efforts in Nigeria, 1960-2010. Studies in Sociology of Science, 3(3), 48-56.

Okafor, K. (2017). Agricultural policies in Nigeria and why they failed Read more.

Olaseni, M., \& Alade, W. (2012), Vision 20:2020 and the Challenges of Infrastructural Development in Nigeria, Journal of Sustainable Development, 5(2), 63-66. https://doi.org/10.5539/jsd.v5n2p63

Olatunbosun, D. (1973). Nigerian's Neglected Majority. Ibadan: NISER, Oxford University Press.

Omotoso, O. (2009). Accessibility to Medical Facilities in the Rural Areas of Ekiti State, Nigeria. African Research Review, 3(5), 29-39. https://doi.org/10.4314/afrrev.v3i5.51139

O'neil, P. (2014). Financing of rural infrastructure and services trends, achievements and challenges. World Bank.

Payne, G., \& Payne, J. (2004). Key Concepts in Social Research. SAGE key concepts. https://doi.org/10.4135/9781849209397

Raheem, W. M., \& Bako, A. I. (2014). Sustainable Rural Development Programmes In Nigeria: Issues And Challenges. Asian Journal of Science and Technology, 5(9), 577-586.

Raphael, L. M. (2012). Role of Public Private Partnerships in Rural Infrastructure in India. Finance Articles.

Rajaraman, I. (2005). Financing Rural Infrastructure in Developing Countries: The Case of India. Applied Econometrics and International Development, 5(2), 53-68.

REAP. (2006). Renewable Electricity Action Program: International Centre for Energy Environment and Development; Federal Ministry of Power and Steel, Abuja, Nigeria.

Sambe, M. (2018). Rethinking Roads in Nigeria. Stears Business.

SCPDC (2018). Infrastructural Projects.

Welcome, M. O. (2011). The Nigerian health care system: Need for integrating adequate medical intelligence and surveillance systems. Journal of Pharmacy and BioAllied Sciences, 3(4), 470-478. https://doi.org/10.4103/0975-7406.90100

World Bank. (2005). Nigeria: expanding access to rural infrastructure issues and options for rural electrification, water supply and telecommunications (English). Energy Sector Management Assistance Programme (ESMAP) technical paper series; no. 91. Washington, DC: World Bank. 


\section{Macrothink}

Journal of Social Science Studies

ISSN 2329-9150

2019, Vol. 6, No. 2

World Bank. (2012). Agricultural Development Projects in Nigeria. Independent Evaluation Group.

Yusuf, M. O. (2007). Private Sector Initiatives and Infrastructural Development in Nigeria.

\section{Copyright Disclaimer}

Copyright for this article is retained by the author(s), with first publication rights granted to the journal.

This is an open-access article distributed under the terms and conditions of the Creative Commons Attribution license (http://creativecommons.org/licenses/by/3.0/). 